\title{
Effect of salinity on the growth of Dasya pedicellata
}

\author{
S. Nygren \\ Marine Botanical Institute; Göteborg, Sweden
}

KURZFASSUNG: Einfluß des Salzgehalts auf das Wachstum von Dasya pedicellata. Die Rotalge Dasya pedicellata J. AG. hat in letzter Zeit Teile der niederländischen und schwedischen Küsten besiedelt. Das nächstgelegene Vorkommen außerhalb dieser Gebiete findet sich in Südspanien. Die verschiedenen neuen Standorte sind von gleicher Beschaffenheit; sie sind charakterisiert durch niedrigen Salzgehalt, das Fehlen von Gezeiten sowie durch mehr oder weniger starke Wasserströmungen. Kulturexperimente mit Pflanzen aus Schweden zeigren, daß Zellen, die durch Zerfall der monosiphonen Fäden entstehen, sich vegetativ vermehren können. Sie entwickeln sich wie die Keimlinge der Fortpflanzungsorgane. Auch ein Teil einer sterilen Pflanze kann zahlreiche neue Pflanzen hervorbringen. Kulturen von Karposporen, Tetrasporen und Zellen aus zerfallenen Fäden zeigen maximales Wachstum in einem Medium, das einen geringeren Salzgehalt als normales Seewasser aufweist. Trotz ihres sublittoralen Vorkommens besitzt $D$. pedicellata eine große Salztoleranz.

\section{INTRODUCTION}

Dasya pedicellata has recently colonized parts of the coasts of the Netherlands and Sweden (Koster 1952, Suneson 1953). The nearest habitat outside these regions is southern Spain; the center areas of distribution of this species are the Mediterranean and the Atlantic coast of North America. The particular biotopes colonized are of the same type, and characterized by low salinity, no tidal influence, more or less pronounced water currents (DEN HARTOG 1964). The salinity of the Swedish localities normally fluctuates between 18 and 30\%. Tetrasporic male and female individuals (with cystocarps) have been found along the Swedish West coast from July to October.

\section{METHOD}

The cultures were grown in Petri dishes containing $50 \mathrm{ml}$ medium, and illuminated with c. 1000 lux fluorescent light for $16 \mathrm{~h}$ a day at $15^{\circ} \mathrm{C}$. The medium consisted of natural sea water (the lower concentrations were obtained by dilution with distilled water) enriched according to the following formula:

$\begin{array}{lcc}\mathrm{NaNO}_{3} & 10 & \mathrm{mg} \\ \mathrm{Na}_{2} \mathrm{HPO}_{4} \cdot 12 \mathrm{H}_{2} \mathrm{O} & 2 & \mathrm{mg} \\ \mathrm{Fe} \text {-citrate } & 0.05 \mathrm{mg} \\ \mathrm{MnSO}_{4} \cdot 4 \mathrm{H}_{2} \mathrm{O} & 0.05 \mathrm{mg} \\ \text { Sea water }(5-30 \%) & 100 \mathrm{ml}\end{array}$

This medium was renewed about every fortnight to prevent iron deficiency. 


\section{RESULTS}

It is known that in culture the monosiphonous branches of Dasya pedicellata disintegrate into single cells or cellaggregates under the influence of unfavourable outside factors (ToBlen 1902). These cells have a great regenerative capacity. In order to investigate the possibility of growth into fully developed plants, a branch of a sterile individual was placed in a small amount of medium. Some days later, parts of the bottom area of the culture vessel were covered with isolated cells (Fig. 1). They settled

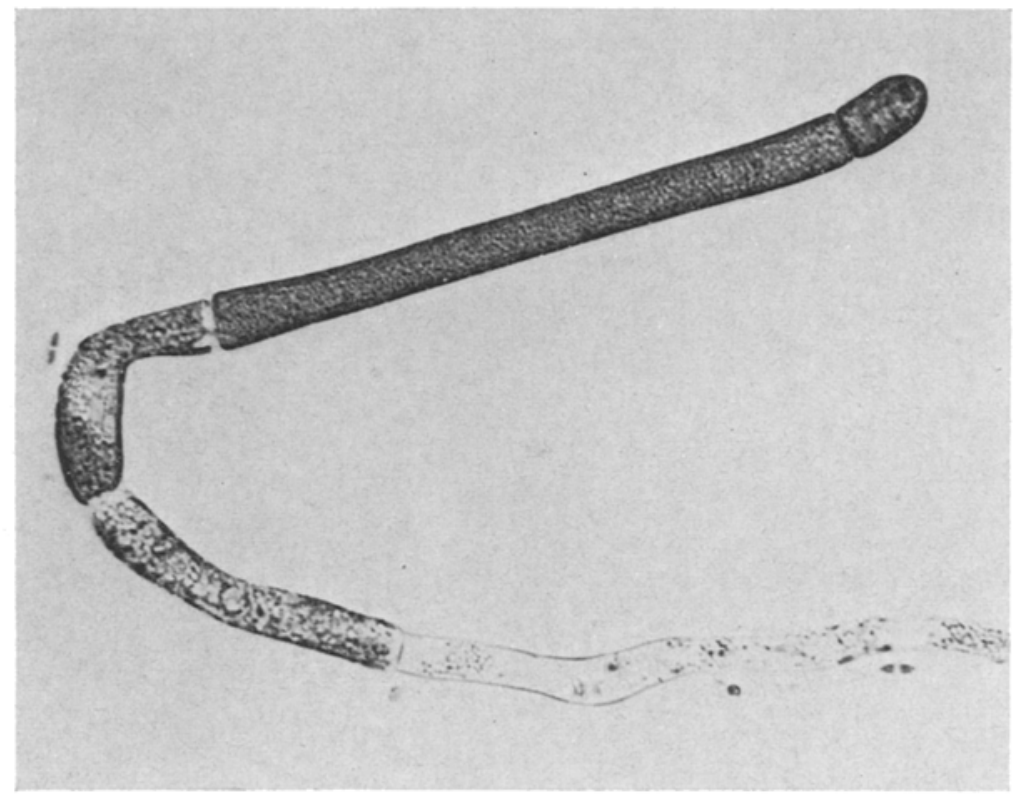

Fig. 1: Dasya pedicellata. Germinating isolated cell from disintegrated monosiphonous branch. $(400: 1)$

and developed in the same way as germlings from reproductive organs. Two months later they reached a length of $10-20 \mathrm{~mm}$ (Fig. 2). Thus these fragments can effect vegetative propagation. Even a part of a plant will give rise to numerous new individuals.

Material for cultures in different salinities was collected in July. Germlings of carpospores, as well as tetraspores from isolated cystocarps and stichidia, were cultivated in media of $5,10,15,20,25$, and $30 \% \mathrm{~S}$. Two months later the growth was found most vigorous in 15-25\% S. Experiments with germlings originating from a culture of isolated cells show maximum growth in $20 \% \mathrm{~S}$ (Tab. 1).

Dasya pedicellata belongs to the sublittoral (on the Swedish West coast it occurs at water depths of 1-6 m). Considering its vertical distribution, it is expected to have a comparatively low resistance towards variations of salt concentrations (BIEBL 1938). However, experiments with material from natural habitats and cultures reveal a 
Table 1

Growth rates of Dasya pedicellata in different salinities after 40 days

\begin{tabular}{|llcccc|}
\hline Salinity (\%) & 5 & 10 & 15 & 20 & 30 \\
Dry weight $(\mathrm{mg})$ & 1.4 & 3.3 & 3.7 & 4.3 & 3.7 \\
\hline
\end{tabular}

resistance range between 0.2 and at least 2.0 times the salt concentration of the sea water used $(25 \% 0 \mathrm{~S})$. The monosiphonous branches show a somewhat greater hypoosmotic resistance than other parts of the thallus. This great range does not correspond to the vertical distribution observed, but represents a prerequisite for distribution in regions with different and varying salinities.

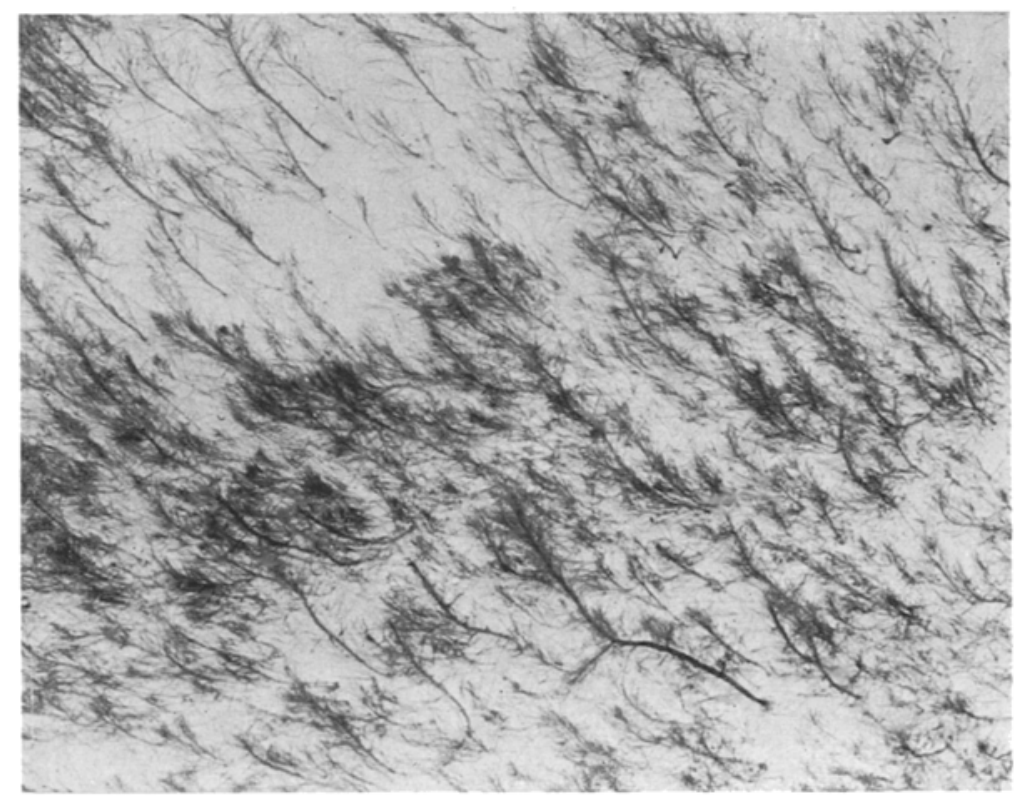

Fig. 2: Dasya pedicellata. Plantlets originating from isolated cells. $(2: 1)$

These culture experiments, as well as the occurrence of Dasya pedicellata in the Netherlands and Sweden, indicate that it is euryhaline with maximum growth rates in polyhaline waters.

\section{SUMMARY}

1. Isolated cells from disintegrated monosiphonous branches of the rhodophycean Dasya pedicellata are able to grow into fully developed plants and to perform vegetative propagation.

2. Cultures of germlings from those cells, as well as carpospores and tetraspores, attain maximum growth rates in salinities lower than that of normal sea water. 
3. In spite of its sublittoral occurrence, Dasya pedicellata tolerates a wide range of salinities.

\section{LITERATURE CITED}

BIEbL, R., 1938. Trockenresistenz und osmotische Empfindlichkeit der Meeresalgen verschieden tiefer Standorte. Jb. wiss. Bot. 86, 350-386.

Hartog, C. Den, 1964. Ecology of Dasya pedicellata in the Netherlands. Int. Seaweed Symp. 4 (Biarritz), 197-201.

Koster, J. Th., 1952. Rare or otherwise interesting marine algae from the Netherlands. Acta bot. néerl. 1, 201-215.

Suneson, S., 1953. Algforskningen på Kristineberg. K. svenska VetenskAkad. Ärsb. 1953, 461-478.

ToвLER, F., 1902. Zerfall und Reproductionsvermögen des Thallus einer Rhodomelacee. Ber. dt. bot. Ges. 20, 357-365.

Author's address: Dr. S. Nygren

Marine Botanical Institute

Frölundgatan 22

Göteborg, Sweden 